\title{
DISTANCE LEARNING AT FUTURE STARS KINDERGARTEN
}

\author{
Witarsjah Stephanus ${ }^{1}$ \\ Management Department, BINUS Business School Undergraduate Program, \\ Bina Nusantara University \\ Jl. Kebon Jeruk Raya No. 27, Kebon Jeruk, Jakarta 11530, Indonesia \\ witarsyah@binus.ac.id
}

Received: January $21^{\text {st }}, 2020 /$ Revised: February $12^{\text {th }} 2020 /$ Accepted: February $24^{\text {th }}, 2020$

\begin{abstract}
The Covid-19 pandemic, which began to spread in Indonesia since March 2020, has made many activities to take place at home. The government asks all Indonesians to work from home, worship from home, and learn from home. This is done so that the virus does not spread and cause even greater casualties. Learning from home is one way to prevent students from the dangers of the Covid-19 virus. Starting from the level of early childhood education to higher education are required to carry out distance learning using technology assistance such as video calls with Hangouts, Zoom, Skype, and Webex. Future Stars Preschool also has to do distance learning using the video call method and each parent is asked to prepare their child at home so they can take online classes with written material that has been prepared in advance. Parents are also asked to take photos of their children doing homework to be emailed and the materials that have been done are sent to school at the end of the period. Schools must determine what video call application to use so that each child can take part in distance learning, as well as the method of delivering material to each child. The applications used should be easy and not burdensome for parents, and also the delivery or processing of materials can be easier for early childhood children.
\end{abstract}

Keywords: learning, technology, video call,Online

\section{Preliminary}

Future Stars Preschool is a school for early childhood located in Central Jakarta. The school uses a Cambridge curriculum that focuses on child development. The language of instruction used is English as well as Indonesian and Mandarin.

\section{The school's vision is:}

We are devoted to mold children into world citizens of tomorrow prepared with knowledge, moral attributes, spiritual approach, dedication and love for the human kind through the application of latest and appropriate educational tools.

\section{The school's mission is:}

- To offer a self-motivated educational program to students of diverse backgrounds which allow them to enrich themselves and the society through their confidence and integrity.

- To nurture and enhance the skills, aptitude and attitude required of a student to be a global citizen.

- To inspire each student to achieve his / her highest potential; to practice healthy ethics and be compassionate human beings who will commit themselves to creating a peaceful world.

To continue fulfil the vision and mission of the school during this pandemic, schools must adapt learning methods to students with online video call meetings using the concept of online learning. Child 
development according to the Cambridge curriculum must also be done so that every child can grow and develop.

The term online learning appears as a form of learning pattern in the era of information technology as it is today. Online is an acronym for "in the network" instead of the word online which we often use in connection with internet technology. Online is a translation of the term online which means connected to the internet network. Online learning means learning that is done online, using learning applications or social networks. Online learning is learning that is carried out without doing face-to-face, but through existing platforms. All forms of subject matter are distributed online, communication is also carried out online, and tests are also carried out online. This online learning system is assisted by several applications, such as Google Classroom, Google Meet, Edmudo and Zoom.

The success of learning media is not only seen from a technical side but also depends on the characteristics of each student. Nakayama M (2007) revealed that all literature in e-learning indicates that not all students will be successful in online learning. This is due to the learning environment and the characteristics of each student.

\section{Implementation \& Method}

There are several video calling applications that are commonly used so far, namely Hangouts, Zoom, Skype and Webex. From some of these applications it is necessary to determine applications that provide good quality without burdening schools or parents.

According to the summary conducted by Tanyadigital, Zoom is the best video conferencing application in 2020. Zoom provides many complete features such as number of participants, cloud storage, and also virtual backgrounds.

According to tests conducted by Hutchinson 3 (Tri), it was found that Zoom is an application that uses the least amount of data for a 30-minute video call with 5 participants.
Table 1. Bandwith Usage

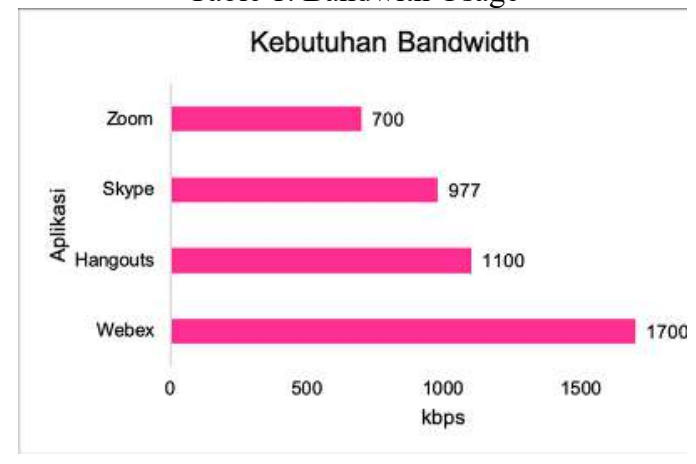

\section{Results and Discussion}

From a survey of 29 parents of K2 class students, it can be seen that the parents are satisfied and helped by the use of the Zoom application during this distance learning.

1. Would you agree with schools to conduct distance learning during the Covid-19 pandemic?

a. All the parents agreed

2. How many times do you participate in children's school activities online a week?

a. 20 parents answered: 0 - once a week

b. 5 parents answered: 2-3 times a week

c. 4 parents answered: 4-5times a week

3. Can the Zoom application be used help your child's distance learning?

a. All the parents agreed

4. Are you satisfied and helped by using the Zoom application?

a. All the parents agreed

\section{Conclusion}

The Zoom application really helps Future Stars Preschool in distance learning during the Covid-19 pandemic, because it can continue to carry out face-to-face learning activities for every student who goes to school here. The school's vision and mission can still be achieved through the Zoom application. 
For parents it is also very helpful with the Zoom application, where schools for their children are still carried out by being taught directly by teachers even though they are online. Every child can still learn and grow and develop that parents expect through schooling can also happen.

\section{Suggestion}

Sound and picture quality when zooming is sometimes intermittent and inaudible, so that every parent has a guaranteed telecommunication provider with affordable data costs.

\section{References}

https://tanyadigital.com/11-aplikasi-videoconference-terbaik-untuk-kerja-atau-bisnis/

https://tekno.kompas.com/read/2020/04/01/12 010057/hangouts-zoom-skype-dan-webexmana-yang-paling-irit-data

Nakayama M, Yamamoto H, \& S. R. (2007). The Impact of Learner Characterics on Learning

Performance in Hybrid Courses among Japanese Students. Elektronic Journal ELearning, Vol.5(3) 